\title{
INVENTARISASI JENIS-JENIS TANAMAN HIAS INTRODUKSI DI DESA PENGLIPURAN, KABUPATEN BANGLI, BALI
}

\section{(VARIETY OF DECORATIVE PLANTS INTRODUCTION'S INVENTORISATION IN PANGLIPURAN VILLAGE, BANGLI DISTRICT, BALI)}

\author{
Ayu Zuraida *, A.A. Gde Raka Dalem**, Martin Joni* \\ *Program Studi Biologi, FMIPA, Universitas Udayana \\ Bukit Jimbaran, Bali, ayurazura@gmail.com \\ ** Kelompok Studi Ekowisata dan Pembangunan Berkelanjutan, FMIPA, Universitas Udayana, Bali, \\ sustainablebali@yahoo.com
}

\section{INTISARI}

Desa Penglipuran adalah salah satu desa adat di Bali yang masih mengutamanakan kerukunan dan kebersamaan. Desa ini berlokasi di Kelurahan Kubu, Kecamatan Bangli, Kabupaten Bangli, Bali. Tanaman di Desa Penglipuran sangat beragam jenisnya. Keanekaragaman jenis tanaman tersebut dapat disebabkan oleh beberapa faktor, salah satunya karena introduksi. Penelitian ini dilakukan untuk mengetahui jenis tanaman hias yang diintroduksi di Desa Penglipuran, dengan tujuan untuk memberikan informasi kepada masyarakat mengenai tanaman tersebut agar dapat dimanfaatkan potensinya pada destinasi wisata lain, khususnya yang ada di Bali. Metode penelitian yang digunakan adalah purposive sampling. Data diperoleh melaui pengamatan langsung di lapangan dan wawancara terhadap masyarakat setempat, kemudian diidentifikasi di Laboratorium Taksonomi Tumbuhan FMIPA, Universitas Udayana. Berdasarkan hasil penelitian diperoleh 32 jenis dari 24 suku (famili) tanaman introduksi. Tanaman hias introduksi di Desa Penglipuran dapat dikelompokkan menjadi 3 kelompok yaitu tanaman hias bunga sebanyak 22 jenis, tanaman hias daun sebanyak 8 jenis dan tanaman hias batang sebanyak 1 jenis.

Kata Kunci: inventarisasi, Desa Penglipuran, tanaman hias, introduksi

\section{ABSTRACT}

Panglipuran Village is one of the traditional villages in Bali that still prioritizes harmonization and sense of togetherness. The village is located in Kelurahan Kubu, Kecamatan Bangli, Bangli District, Bali. Panglipuran Village has many types of plants. The varieties of plants can be influenced by several factors: one of them is introduction. This research is conducted to examine the introduction of decorative plants in Panglipuran Village, with the purpose of providing information to villagers about those plants, so that their potential can be utilized in other travel destinations, especially the ones in Bali. The method used in this research is purposive sampling. Data were obtained through direct field observation and interviews with local villagers, and later were identified at Laboratorium Taksonomi Tumbuhan FMIPA, Udayana University. According to the results of this research, 32 types of introduction plants which comes from 24 different famili was found. Introduction of decorative plants in Panglipuran Village can be classified into 3 groups, which are 22 types of decorative flower plants, 8 types of decorative leaf plants, and a single type of decorative stem plants.

Keywords: inventorisation, Panglipuran Village, decorative plants, introduction

\section{PENDAHULUAN}

Desa Penglipuran adalah salah satu desa adat di Bali yang masih mengutamanakan kerukunan dan kebersamaan serta kearifan lokal. Desa ini berlokasi di Kelurahan Kubu, Kecamatan Bangli, Kabupaten Bangli (Agus, 2015). Desa Penglipuran memiliki luas keseluruhan sekitar 112 hektar serta berada 700 meter diatas permukaan air laut. Desa ini juga telah dianugrahi penghargaan kalpataru dikarenakan kelestarian lingkungannya sangat terjaga dengan baik. (Wulansari dah Suhirman, 2012).

Tanaman di Desa Penglipuran sangat beragam jenisnya. Keanekaragaman jenis tersebut dapat disebabkan oleh beberapa faktor diantaranya, variasi perkembangan yang disebabkan oleh faktor genetik, variasi lingkungan yang meliputi ketinggian, iklim, letak geografis serta dapat pula oleh campur tangan manusia (Anshori dkk., 2009). Sebagian besar tanaman yang ada di Desa Penglipuran tersebut dapat digolongkan ke dalam tanaman hias introduksi.

Introduksi tanaman merupakan suatu proses memperkenalkan tanaman dari tempat asal tumbuhnya ke suatu daerah baru. Introduksi tanaman yang dimaksudkan adalah mendatangkan atau memasukkan varietas-varietas tanaman dari luar negeri ke suatu negeri (Mangoendidjojo, 2007). Tanaman introduksi dapat dikelompokkan menjadi tiga yaitu introduksi tanaman yang merupakan tanaman baru di suatu wilayah, introduksi tanaman yang merupakan suatu varietas baru, dan introduksi tanaman karena tanaman atau varietas ini mempunyai keunggulan tertentu (Suryadi dkk., 2004).

Seperti yang telah diketahui bahwa tanaman hias sering digunakan untuk menambah nilai estetika dan kecantikan pada suatu tempat, sehingga Desa Penglipuran ini memiliki daya tarik bagi wisatawan yang berkunjung. Tanaman hias dapat dikelompokan menjadi 5, yaitu tanaman hias buah, tanaman hias bunga, tanaman hias daun, tanaman hias batang dan tanaman hias akar. Sedangkan menurut tempatnya, tanaman hias dapat dikelompokan menjadi 3 yaitu tanaman hias biasa, tanaman hias gantung dan tanaman hias air (Handayati, 2013).

Penelitian ini dilakukan untuk mengetahui jenis tanaman hias yang diintroduksi di Desa Penglipuran, dengan tujuan untuk memberikan informasi kepada masyarakat mengenai tanaman tersebut agar dapat 
dimanfaatkan potensinya pada tempat wisata lain, khususnya yang ada di Bali.

\section{MATERI DAN METODE}

Penelitian ini dilaksanakan di Desa Penglipuran, Kelurahan Kubu, Kecamatan Bangli, Kabupaten Bangli. Penelitian dilakukan pada bulan Desember 2016. Alat yang digunakan antara lain alat tulis (kertas dan pulpen), alas berupa papan kayu serta kamera Canon (TM: EOS 600D: Jepang). Bahan atau sampel pada penelitian ini yaitu yang beragam jenis tanaman hias introduksi yang ditemukan di kawasan Desa Penglipuran. Metode penelitian yang digunakan yaitu purposive sampling.
Pengumpulan data dilakukan dengan cara dokumentasi, kepustakaan menggunakan buku Ensiklopedia Flora (Steenis dkk., 2007) dan identifikasi di Laboratorium FMIPA, Universitas Udayana.

\section{HASIL}

Hasil penelitian di Desa Penglipuran diperoleh 32 jenis tanaman hias dari 24 suku (famili). Tanaman hias yang ditemukan tersebut hanya dapat dikelompokan menjadi 3 yaitu kelompok tanaman hias bunga sebanyak 22 jenis, tanaman hias daun sebanyak 8 jenis dan tanaman hias batang sebanyak 1 jenis. Hasil tersebut dapat dilihat pada Tabel 1.

Tabel 1. Jenis-jenis tanaman hias introduksi di Desa Penglipuran

\begin{tabular}{|c|c|c|c|c|}
\hline No & $\begin{array}{l}\text { Famili, Nama Lokal dan } \\
\text { Jenis }\end{array}$ & K. TH & Asal & Manfaat \\
\hline 1. & $\begin{array}{l}\text { Acanthaceae } \\
\text { 1. Bunga Lilin } \\
\quad \text { (Pachystachys lutea) }\end{array}$ & 1. Bunga & 1. Amerika & 1. Bunga dapat digunakan sebagai obat diare dan cacingan. \\
\hline 2. & $\begin{array}{l}\text { Amaranthaceae } \\
\text { 2. Jengger Ayam } \\
\text { (Celosia cristata } \mathrm{L} .) \\
\text { 3. Bayam Hias } \\
\text { (Amaranthus tricolor) } \\
\text { 4. Ratna } \\
\text { (Gomphrena globosa } \\
\text { L.) }\end{array}$ & $\begin{array}{l}\text { 2. Bunga } \\
\text { 3. Daun } \\
\text { 4. Bunga }\end{array}$ & $\begin{array}{l}\text { 2. - } \\
\text { 3. Amerika } \\
\text { Tropic } \\
\text { 4. Brazil }\end{array}$ & $\begin{array}{l}\text { 2. Bunga dapat digunakan untuk mengobati batuk, muntah } \\
\text { darah, wasir atau ambien dan dapat menghentikan } \\
\text { mimisan (Mursito dan Heru, 2011) } \\
\text { 3. Tanaman dapat digunakan sebagai penghias halaman. } \\
\text { 4. Bunga dapat digunakan untuk kegiatan upacara }\end{array}$ \\
\hline 3. & $\begin{array}{l}\text { Amaryllidaceae } \\
\text { 5. Bunga Desember } \\
\text { (Haemanthus } \\
\text { multiflorus) }\end{array}$ & 5. Bunga & $\begin{array}{l}\text { 5. Sub-Saharan } \\
\text { Afrika }\end{array}$ & 5. Tanaman dapat digunakan sebagai pengias halaman. \\
\hline 4. & $\begin{array}{l}\text { Apocynaceae } \\
\text { 6. Tapak Dara } \\
\text { (Catharanthus roseus) } \\
\text { 7. Jepun } \\
\text { (Plumeria acminate.) } \\
\text { 8. Alamanda } \\
\text { (Allamanda } \\
\text { cathartica) }\end{array}$ & $\begin{array}{l}\text { 6. Bunga } \\
\text { 7. Bunga } \\
\text { 8. Bunga }\end{array}$ & $\begin{array}{l}\text { 6. Madagas- } \\
\text { kar } \\
\text { 7. Asia } \\
\text { Tenggara } \\
\text { 8. Amerika } \\
\text { Tengah dan } \\
\text { Selatan }\end{array}$ & $\begin{array}{l}\text { 6. Daun dapat digunakan untuk mengobati penyakit } \\
\text { diabetes militus, batu ginjal, leukimia, luka bakar, dan } \\
\text { gondok (Soriton dkk., 2014). } \\
\text { 7. Bunga dapat digunakan untuk upacara keagamaan dan } \\
\text { penghias halaman. } \\
\text { 8. Bunga memiliki beberapa fungsi medis, salah satunya } \\
\text { dapat di-gunakan sebagai laksatif atau pencahar untuk } \\
\text { mengatasi sem-belit (Djimantoro dan Yolanda, 2014). }\end{array}$ \\
\hline 5. & $\begin{array}{l}\text { Araceae } \\
\text { 9. Anthurium } \\
\text { (Antuhurium } \\
\text { andreanum) }\end{array}$ & 9. Bunga & 9. Jawa & $\begin{array}{l}\text { 9. Tanaman dapat digunakan sebagai penghias halaman dan } \\
\text { bunga dapat dijadikan sebagai bunga potong. }\end{array}$ \\
\hline 6. & $\begin{array}{l}\text { Arecaceae } \\
\text { 10. Palem } \\
\quad \text { (Ravenea } \text { sp.) }\end{array}$ & 10. Daun & 10. Indonesia & 10. Tanaman dapat dijadikan sebagai penghias halaman. \\
\hline 7. & $\begin{array}{l}\text { Aspleniaceae } \\
\text { 11. Paku Sarang Burung } \\
\text { (Asplenium nidus L.) }\end{array}$ & 11. Daun & $\begin{array}{l}\text { 11. Afrika } \\
\text { Timur dan } \\
\text { seluruh hutan } \\
\text { tropis }\end{array}$ & $\begin{array}{l}\text { 11. Daun dapat digunakan sebagai penyubur rambut, obat } \\
\text { demam, radang dan melancarkan peredaran darah (Ceri } \\
\text { dkk., 2014). }\end{array}$ \\
\hline 8. & $\begin{array}{l}\text { Asteraceae } \\
\text { 12. - } \\
\text { 13. Bunga Matahari } \\
\quad \text { (Helianthus annuus L.) } \\
\text { 14. Gemitir } \\
\quad \text { (Tagetes erecta) }\end{array}$ & $\begin{array}{l}\text { 12. Bunga } \\
\text { 13. Bunga } \\
\text { 14. Bunga }\end{array}$ & $\begin{array}{l}\text { 12. - } \\
\text { 13. Mexico } \\
\text { 14. Amerika } \\
\text { Selatan }\end{array}$ & $\begin{array}{l}\text { 12. Bunga dapat dijadikan bunga potong dan penghias } \\
\text { ruangan. } \\
\text { 13. Bunga dapat dijadikan sebagai bunga potong. Selain itu, } \\
\text { biji bunga juga dapat digunakan sebagai sumber minyak } \\
\text { untuk menggoreng, mengentalkan dan sebagai cam- } \\
\text { puran salad (Katja, 2012). } \\
\text { 14. Bunga digunakan untuk kegiatan upacara keagamaan. }\end{array}$ \\
\hline 9. & $\begin{array}{l}\text { Begoniaceae } \\
\text { 15. Begonia } \\
\quad \text { (Begonia } \mathrm{sp.})\end{array}$ & 15. Daun & 15. Brazil & $\begin{array}{l}\text { 15. Tanaman dapat dijadikan sebagai penghias halaman dan } \\
\text { ruangan }\end{array}$ \\
\hline 10. & $\begin{array}{l}\text { Cactaceae } \\
\text { 16. Kaktus }\end{array}$ & 16. Batang & $\begin{array}{l}\text { 16. Benua } \\
\text { Amerika }\end{array}$ & 16. Tanaman dapat dijadikan sebagai penghias halaman. \\
\hline 11. & $\begin{array}{l}\text { Equisetaceae } \\
\text { 17.Paku Ekor Kuda } \\
\quad \text { (Equisetum sp.) }\end{array}$ & 17. Daun & $\begin{array}{l}\text { 17. Asia } \\
\text { Tenggara }\end{array}$ & $\begin{array}{l}\text { 17. Tanaman dapat dijadikan sebagai penghias halaman, } \\
\text { baik dalam wadah pot. }\end{array}$ \\
\hline 12. & $\begin{array}{l}\text { Euphorbiaceae } \\
\text { 18. Puring } \\
\quad \text { (Codiaeum variegatum })\end{array}$ & 18. Daun & 18. Indonesia & $\begin{array}{l}\text { 18. Air rebusan daun puring dapat diminum untuk } \\
\text { memperlancar keluarnya keringat dan mampu } \\
\text { menurunkan panas tubuh akibat demam (Purwanto dan } \\
\text { Aziz, 2007). }\end{array}$ \\
\hline 13. & $\begin{array}{l}\text { Heliconiaceae } \\
\text { 19. Heliconia }\end{array}$ & 19. Bunga & 19. Asia & 19. Tumbuhan dapat digunakan sebagai penghias halaman. \\
\hline
\end{tabular}




\begin{tabular}{|c|c|c|c|c|}
\hline & $\begin{array}{l}\text { (Heliconia } \\
\text { psittacorum) }\end{array}$ & & & \\
\hline 14. & $\begin{array}{l}\text { Laminaceae } \\
\text { 20. Salvia } \\
\quad \text { (Urena lobata L.) }\end{array}$ & 20. Bunga & 20. Brazil & $\begin{array}{l}\text { 20. Daun dapat digunakan sebagai obat malaria, nyeri sendi, } \\
\text { rematik, dan peradangan usus (Limbong dkk., 2016) }\end{array}$ \\
\hline 15 & $\begin{array}{l}\text { Myrtaceae } \\
\text { 21. Pucuk Merah } \\
\quad \text { (Oleana syzygium) }\end{array}$ & 21. Daun & 21. - & $\begin{array}{l}\text { 21. Tanaman dapat digunakan sebagai pengias halaman dan } \\
\text { pembatas jalur hijau. }\end{array}$ \\
\hline 16. & $\begin{array}{l}\text { Nephrolepidaceae } \\
\text { 22.Paku Pedang } \\
\quad \text { (Nephrolepis } \mathrm{sp} .)\end{array}$ & 22. Daun & $\begin{array}{l}\text { 22. Asia } \\
\text { Tenggara }\end{array}$ & 22. Tanaman dapat digunakan sebagai penghias halaman. \\
\hline 17. & $\begin{array}{l}\text { Nyctaginaceae } \\
\text { 23. Kembang Kertas } \\
\text { (Bougainvillea } \\
\text { spectabilis) } \\
\text { 24. Bunga Pukul Empat } \\
\text { (Mirabilis jalapa) } \\
\text { 25. Amarilis } \\
\text { (Amarilis } \mathrm{sp} .)\end{array}$ & $\begin{array}{l}\text { 23. Bunga } \\
\text { 24. Bunga } \\
\text { 25. Bunga }\end{array}$ & $\begin{array}{l}\text { 23. Amerika } \\
\text { Selatan } \\
\text { 24. Afrika } \\
\text { Selatan } \\
\text { 25. Amerika } \\
\text { Selatan }\end{array}$ & $\begin{array}{l}\text { 23. Tanaman dapat digunakan sebagai penghias halaman. } \\
\text { 24. Bunga dapat digunakan sebagai bunga potong ataupun } \\
\text { penghias ruangan } \\
\text { 25. Daun dan akar dapat digunakan sebagai obat infeksi } \\
\text { saluran kemih dan bisul. Selain itu, daun juga memiliki } \\
\text { kandungan kimia seperti saponin, flavonoid dan tanin. } \\
\text { Sedangkan akar memiliki kandu-ngan kimia betaxanthin, } \\
\text { dan trigonelin. Kandungan kimia aktif ini yang dapat } \\
\text { digunakan sebagai antibakteri (sani dkk., 2015) }\end{array}$ \\
\hline 18. & $\begin{array}{l}\text { Nymphaceae } \\
\text { 26. Teratai } \\
\quad \text { (Nymphaea alba }\end{array}$ & 26. Bunga & 26. Mesir & 26. Bunga dapat digunakan untuk upacara keagaman. \\
\hline 19. & $\begin{array}{l}\text { Oleaceae } \\
\text { 27. Melati } \\
\text { (Jasminum Officinale) }\end{array}$ & 27. Bunga & 27. Eurasia & $\begin{array}{l}\text { 27. Bunga dapat diekstrak untuk mengasilkan minyak atsiri. } \\
\text { Selain itu dapat mengobati nyeri sendi dan otot (Ningsih } \\
\text { dkk., 2016) } \\
\text { Bunga juga dapat dirangkai untuk menjadi perlengkapan } \\
\text { pernikahan adat Jawa. }\end{array}$ \\
\hline 20. & $\begin{array}{l}\text { Orchidaceae } \\
\text { 28. Angrek } \\
\quad \text { (Dendrobium sp.) }\end{array}$ & 28. Bunga & $28 . \quad-$ & $\begin{array}{l}\text { 28. Bunga dapat dijadikan sebagai bunga potong, dan } \\
\text { penghias halaman ataupun ruangan. }\end{array}$ \\
\hline 21. & $\begin{array}{l}\text { Polypodiaceae } \\
\text { 29. Paku Tanduk Rusa } \\
\text { (Platycerium } \\
\text { bifurcatum) }\end{array}$ & 29. Daun & 29. Jawa & $\begin{array}{l}\text { 29. Daun dapat dijadikan obat herbal atau tradisional untuk } \\
\text { mengobati penyakit demam, bisul, dan bagi wanita hamil } \\
\text { dapat digunakan sebagai obat menyuburkan kan-dungan } \\
\text { (Nurikasiwi, 2017) }\end{array}$ \\
\hline 22. & $\begin{array}{l}\text { Rosaceae } \\
\text { 30. Mawar } \\
\quad(\text { Rosa } \text { sp. })\end{array}$ & 30. Bunga & $30 . \quad-$ & $\begin{array}{l}\text { 30. Tanaman dapat dijadikan sebagai penghias halaman. } \\
\text { Daun dapat dijadikan obat dari gigitan se-rangga } \\
\text { (Mursito dan Heru, 2011) }\end{array}$ \\
\hline 23. & $\begin{array}{l}\text { Rubiaceae } \\
\text { 31. Soka } \\
\quad(\text { Ixora javanica })\end{array}$ & 31. Bunga & 31. Jawa & $\begin{array}{l}\text { 31. Tanaman dapat digunakan seba-gai penghias halaman } \\
\text { dan bunga dapat memikat kupu-kupu. Kulit batang dapat } \\
\text { digunakan sebagai astrigent dan penenang rahim, obat ini } \\
\text { akan bekerja langung pada bagian otot rahim yang } \\
\text { merangasang endometrium dan jaringan ovarium } \\
\text { (Dontha dkk., 2014). }\end{array}$ \\
\hline 24. & $\begin{array}{l}\text { Solanaceae } \\
\text { 32. Petunia } \\
\quad \text { (Petunia sp.) }\end{array}$ & 32. Bunga & $\begin{array}{l}\text { 32. Amerika } \\
\text { Selatan }\end{array}$ & 32. Tanaman dapat dijadikan sebagai penghias halaman \\
\hline
\end{tabular}

Keterangan:

$\mathrm{K}$. $\mathrm{TH}=$ Kelompok Tanaman Hias

\section{PEMBAHASAN}

Tanaman hias di Desa Penglipuran sangat beragam, baik jenis maupun kelompoknya (Tabel 1). Menurut Sutarno dan Setyawan (2015), keanekaragaman tanaman hias pada suatu daerah dapat terjadi karena campur tangan manusia. Suryadi dkk. (2004) menyatakan bahwa tingginya jumlah kelompok tanaman hias dapat disebabkan oleh adanya proses introduksi tanaman. Selain itu, berdasakan hasil wawancara di lapangan terhadap beberapa warga lokal, tanaman-tanaman hias introduksi tersebut diperoleh dari hasil sumbangan donatur untuk membantu pembangunan desa.

Berdasarkan hasil penelitian yang telah dilakukan, diketahui bahwa kelompok tanaman hias bunga berjumlah 22 jenis. Menurut tanaman hias bunga merupakan tanaman yang mempunyai bunga berpesona cantik dengan satu atau banyak warna. Tanaman hias bunga dapat menambah keindahan suatu lingkungan di sekitarnya serta membuatnya terlihat lebih asri. Selain itu, tanaman hias bunga juga mempunyai aroma yang wangi tergantung dari jenisnya, sehingga mampu menjadi daya tarik wisatawan yang berkunjung ke Desa penglipuran. Perlu diketahui juga, bahwa salah satu etnis yang masih memegang teguh budaya dan memanfaatkan tanaman hias bunga adalah masyarakat Desa Penglipuran. Contoh pemanfaatan tanaman hias bunga yaitu digunakan dalam berbagai ritual seperti untuk upacara keagamaan, kematian dan perkawinan.

Kelompok tanaman hias bunga yang ada di Desa Penglipuran ini sebagian dapat dimanfaatkan sebagai tanaman upakara sehingga ditanamam dan dilestarikan oleh masyarakat setempat. Tanaman tersebut diantaranya adalah gemitir, ratna, jepun, dan teratai. Salah satu contoh tanaman hias bunga tersebut adalah gemitir, merupakan tanaman yang berasal dari Amerika Selatan. Pada wilayah Desa Penglipuran gemitir dapat tumbuh dengan baik. Hal tersebut dikarenakan syarat tumbuh tanaman gemitir sangat mudah yaitu cukup dengan paparan sinar matahari, ditanaman pada tanah yang memiliki $\mathrm{pH}$ netral, dan pengairan yang baik, begitu pula dengan tanaman yang dapat digunakan untuk upakara lainnya (Winarto, 2010). 
Kelompok tanaman hias bunga lainnya yaitu Dendrobium sp. dari famili Orchidaceae yaitu anggrek. Menurut Hartati dan Linayanti (2015) salah satu jenis tanaman hias penting di dunia adalah anggrek karena merupakan salah satu tumbuhan berbunga yang banyak tersebar dan beraneka ragam di dunia. Anggota dari famili ini dapat ditemukan di seluruh dunia, kecuali padang pasir yang kering dan daerah yang selalu tertutup salju. Widiastoety dkk. (2010) menyatan bahwa kontribusi anggrek Indonesia dalam khasanah anggrek dunia cukup besar. Terdapat 20.000 jenis anggrek yang tersebar di seluruh dunia, 6.000 di antaranya berada di hutan Indonesia, sehingga untuk mengintroduksi tanaman angrek di Desa Penglipuran sangatlah relevan karena penyebaran anggrek terbilang sangat luas dan dapat tumbuh dengan baik pada habitatnya.

Kelompok tanaman hias batang di Desa Penglipuran hanya ditemukan satu jenis yaitu tanaman kaktus. Tanaman ini berasal dari Benua Amerika. Menurut Rukmana dan Yuyun (1998), penemuan fosil kaktus di barat Benua Amerika, diketahui bahwa kaktus telah tumbuh 100 juta tahun silam dengan morfologi lengkap. Terdiri dari batang, cabang, ranting dan daun. Akibat proses evolusi berjuta tahun tersebut, kaktus saat ini memiliki warna yang berbeda dan tidak memiliki daun. Para ahli menyebutnya dengan sisa flora purba dan telah tersebar sampai Benua Asia. Selain ditemukan Desa
Penglipuran, kaktus juga dapat hidup dimana saja. Hal ini dikarenakan tanaman kaktus telah tesebar pada daerah beriklim tropis dan mampu bertahan hidup pada kisaran suhu normal dan memerlukan paparan sinar matahari yang cukup (Lukman, 2016).

Kelompok tanaman hias daun ditemukan sebanyak 8 jenis, dimana 4 jenis diantaranya adalah kelompok pakupakuan. Tanaman tersebut yaitu paku ekor kuda, pedang, tanduk rusa dan sarang burung (Gambar 1). Tanaman paku-pakuan diintroduksi di Desa Penglipuran karena dari segi perwatan terbilang tidak rumit, hal ini dikarenakan sebagaian besar tanaman paku merupakan epifit (akar melekat dibatang pohon), sehingga tidak membutuhkan banyak ruang (Romaidi dkk., 2012). Salah satu contohnya yaitu tanaman paku tanduk rusa yang memiliki penampilan unik karena terdapat dua tipe daun dengan fungsi dan bentuk yang berbeda. Jenis daun yang pertama yaitu daun selalu steril yang berbentuk perisai tegak. Daun berfungsi mengampulkan dedaunan kering dan menangkap air sehingga kelembaban rimpang tanaman dapat terjaga dengan baik. Jenis daun yang kedua yaitu daun yang menjuntai dari pusat daun pertama, memiliki bentuk menyerupai tanduk rusa. Fungsi dari daun kedua ini adalah sebagai pembawa spora yang diletakan di sisi bawah daun, panjang daun ini bisa menjuntai sepanjang satu meter bahkan lebih. Sehingga daun inilah yang menjadi kekhasan tersendiri bagi paku tersebut (Ceri dkk., 2014).

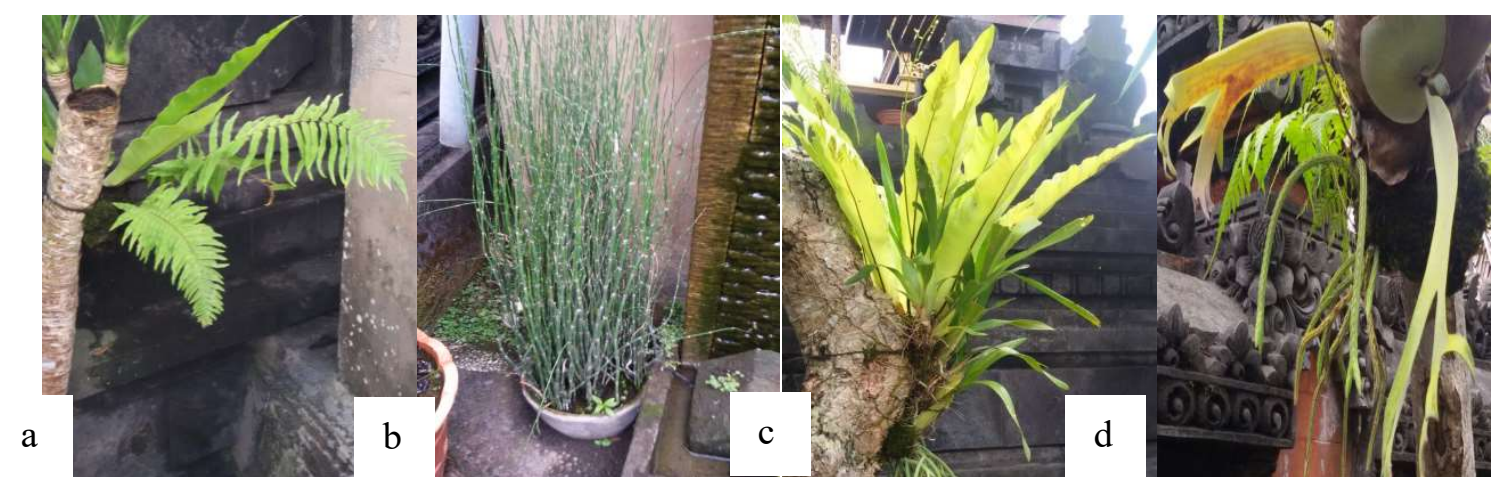

Gambar 1. Jenis paku-pakuan yang ditemukan di Desa Penglipurann. Dari a-d berturut-turut yaitu paku pedang, paku ekor kuda, paku sarang burung dan paku tanduk rusa

\section{SIMPULAN}

Tanaman hias introduksi yang ditemukan di Desa Penglipuran, Kabupaten Bangli, Bali yaitu berjumlah 32 jenis dari 24 famili. Kelompok tanaman hias dapat dikelompokan menjadi 3 yaitu kelompok tanaman bunga sebanyak 22 jenis, tanaman hias daun sebanyak 8 jenis dan tanaman hias batang sebanyak 1 jenis.

\section{SARAN}

Penelitian lebih lanjut yang perlu dilakukan adalah menginventarisasi jenis tanaman hias pada desa wisata lainnya, khususnya yang ada di Bali.

\section{KEPUSTAKAAN}

Agus, W. P. 2015. Valuasi Ekonomi Desa Wisata Penglipuran Kabupaten Bangli, Bali. Megister Ekonomi Pembangunan. Universitas Gadjah Mada. Jogjakarta. Thesis.

Anshori, M. dan Djoko Martono. 2009. Biologi. Pusat Perbukuan Departemen Pendidkan Nasional (BSE). Jakarta
Ceri, B., Irawan, L. dan Riza, L. 2014. Keanekaragaman Jenis Paku-Pakuan (Pteridophyta) Mangrove Muara Sungai Peniti Kecamatan Segedong, Kabupaten Pontianak. J. Probiont. 3(2): 240246.

Djimantoro, I. M. dan Yolanda, D. 2014. Penggunaan Tanaman Hias untuk Meningkatkan Fasilitas Terapi Anak. J. Gomtech. 5(1): 75-84.

Dontha, S., Hemalatha, K. dan Bhagavanraju, M. 2014. Phytochemical and Pharmalogical Profile of Ixora. International Journal of Pharmacetical Sciences and Research. 6(2): 567-584.

Handayati, W. 2013. Perkembangan Pemuliaan Mutasi Tanaman Hias di Indonesia. J. Ilmiah Aplikasi Isotop dan Radiasi. 9(1): 67-80.

Hartati, S. dan Linayanti, D. 2015. Karakterisasi Angrek Alam Secara Morfologi dalam Rangka Pelestarian Plasma Nuftah. J. Agronomi Indonesia. 43(2): 133139. 
Katja, D. G. 2012. Kualitas Minyak Bunga Matahari Komersial dan Minyak Hasil Ekstraksi Biji Bunga Matahari (Helianthus annus L.). J. Ilmiah Sains. 12(1): 1-6.

Limbong, J. D. P. 2016. Keanekaragaman Jenis Tumbuhan Obat di Hutan Kemasyarakatan Kesatuan Pengelolaan Hutan Unit XIV Toba Samosir. Peronema Forestry Science. 5(4): 1-6.

Lukman, S. R. 2016. Uji Daya Hambat Ekstrak Kaktus Pir Berduri (Opuntia ficus indica) Terhadap Petumbuhan Staphylococcus aureus Secara InVitro. Fakultas Kedokteran Gigi. Universitas Hasanuddin. Makasar. Skripsi.

Mangoendidjojo, W. 2007. Dasar-dasar Pemuliaan Tanaman. Kanisius. Jogjakarta.

Mursito, B. dan Heru. 2011. Tanaman Hias Berkhasiat Obat. Swadaya. Jakarta.

Ningsih, R. T., Gunawan, G. dan Eny, D. P. 2016. Kajian PemanfaatanTumbuhan Bunga pada Masyarakat Suku Banjar di Desa Karang Intan Kalimantan Selatan. J. Bioscientiae. 13(1): 37-45.

Nurikasiwi, H. 2017. Kajian Etnobotani Pemanfaatan Tanaman Obat Oleh Masyarakat Baduy Luar, Kabupaten Lebak, Banten. Fakultas Keguruan dan ilmu Pendidikan Biologi. Universitas Pasundan. Thesis.

Purwanto, A. W. dan Aziz, W. 2007. Puring. Kanisius. Jogjakarta.

Romaidi, Marathus, S. dan Eko, B. M. 2012. Jenis-jenis Paku Epifit dan Tumbuhan Inangnya di Tahura Ronngo Soeryo Cangar. J. El-Hayah. 3(1): 8-15.

Rukmanaa, R. dan Yuyun. Y. O. 1998. Tanaman Hias Kaktus. Kanisius. Jogjakarta.

Sani, K. F., Dwi, D. dan Hiut, I. 2015. Uji Efektivitas Antibakteri Ekstrak Etanol Daun Kembang Pukul
Empat (Mirabilis jalapa L.) Terhadap Bakteri Staphylococcus aureus dan Escherichia coli. Pros Semnas dan Workshop Perkembangan Terkini Sains Farmasi dan Klinik 5. 312-316.

Soemarwoto, O. 1994. Ekologi, Lingkungan Hidup dan Pembangunan. Djambatan: Bandung

Soriton, H., Palulina, V. Y. Y. Dan Widya, A. L. 2014. Uji Efektivitas Estrak Etanol Daun Tapak Dara (Catharantus roseus (L.) G. Don) Terhadap Penurunan Kadar Gula Darah Tikus Putih Jantan Galur Wistar (Rattus norvegicus L.) yang Diberi Sukrosa. Jurnal Ilmiah Farmasi. 3(3): 162-169.

Suryadi, Luthfy, K. Yenni, dan Gunawan. 2004. Karakterisasi Koleksi Plasma Nutfah Tomat Lokal dan Introduksi. Buletin Plasma Nutfah. 10(2): 72-76.

Sutarno dan Setyawan. 2015. Biodiversitas Indonesia: Penurunan dan upaya pengelolaan untuk menjamin kemandirian bangsa. Proseding Seminar Masyarakat Biodiversitas Indonesia. 1(1): 1-1.

Widiastoety, D., S. Nina, M. Soedarjo. 2010. Potensi anggrek Dendrobium dalam meningkatkan variasi dan kualitas anggrek bunga potong. Litbang Pertanian. 29(2): 101-106.

Winarto, L. 2010. Tagetes Berguna Bagi Kita. Deptan. BPTP, Sumatera Utara. Tersedia pada: http://sumut. litbang.deptan. go.id/ind/index.php /compo nent/content/article/15-benih/53-tageteserecta-berguna-bagi-kita. (Diakses pada tanggal 14 Januari 2016).

Wulansari dan Suhirman. 2012. Perbandingan Pengendalian Pemanfaatan Ruang Pengendalian Pemanfaatan Ruang Formal. Jurnal Perencanan Wilayah dan Kota A SAPPK V3N1.1(1): 15 